\title{
The effect of Urea-Molasses-Mineral Blocks on rumen parameters and growth performance of buffaloes
}

\author{
VK Kakkar, GS Makka
}

\author{
Department of Animal Nutrition and Forages, Punjab Agricultural University, Ludhiana 141004 (Punjab), India
}

Urea-molasses-mineral blocks (UMMB) has gained recognition as a feed supplement, a maintenance ration (along with crop residues), a part replacement of concentrate mixture and as a corrector of malnutrition in ruminant animals.

We designed two experiments, one on rumen fistulated, and one on growing buffaloes in order to study the effect of UMMB supplementation on rumen parameters and growth performance. The UMMB was prepared by heating urea $(10 \%)$ and molasses $(30 \%)$ together at $110^{\circ} \mathrm{C}$ for 30 minutes. Various diluents (starch and mineral mixture $15 \%$ each, deoiled groundnut cake, deoiled rice bran and sodium chloride $10 \%$ each, and additional $3 \%$ of a feed binder-bentonite) were mixed with the heated product and the whole mass pressed at 1.5 metric ton $/ \mathrm{cm}^{2}$ pressure to produce a rectangular block weighting $3 \mathrm{~kg}$. The $O M$ content of UMMB was $68.2 \%$ and CP $35.9 \%$ on the DM basis.

Rumen fistulated buffaloes (4 in each group) averaging $450 \mathrm{~kg}$ were fed a straw based diet either supplemented with urea (as a part of the concentrate mixture) or with UMMB offered ad $\mathrm{lib}$ and replacing about $1 \mathrm{~kg}$ of the concentrate mixture. Rumen studies showed a consistent release of ammonia in the rumen of UMMB fed animals with higher $(P<0.05)$ amount of microbial protein synthesis (Cline et al, 1958, J Anim Sci, 17, 284-292) as compared with the urea fed animals. This suggested that UMMB provided nitrogen at a rate commensurate with its uptake by the rumen microbes.

In the second experiment, growing buffaloes (6 in each group) were fed 3 types of diet : a control (T1) diet consisting of $2.5 \mathrm{~kg}$ concentrate mixture, $2 \mathrm{~kg}$ green fodder and wheat straw ad lib, a urea diet (T2) in which $50 \%$ of oilseed cake nitrogen in the concentrate mixture was replaced by urea nitrogen and an UMMB diet (T3) having the same schedule as in $T 1$ but removing $1 \mathrm{~kg}$ concentrate mixture and offering UMMB ad lib. The average intake of UMMB was $400 \mathrm{~g} / \mathrm{d} / \mathrm{anim}$. As shown in table below, in spite of lesser total- $\mathrm{N}$ intake and less $\mathrm{N}$-retention, the UMMB group had higher body weight gains $(550 \mathrm{~g} / \mathrm{d})$ as compared with the urea fed group $(512 \mathrm{~g} / \mathrm{d})$ in a 153 day growth study. This result can be due to lower biological value of absorbed $N$ in urea fed (T2) animals (Lewis et al, 1957, Biochem J, 66, 504- 515) and due to gradual licking of UMMB in T3 group. The digestibility coefficients for dry matter, crude protein and crude fiber were nonsignificantly different in the three groups. Additional field studies in respect of malnutrition problems revealed that symptoms like late conception, poor health and long dry periods in cattle and buffaloes got cured to a large extent within 4-18 weeks of UMMB supplementation.

As a conclusion, UMMB can be recommended as a scarcity / famine feed along with crop residues and as a corrector of malnutrition for buffaloes and cattle.

\begin{tabular}{|c|c|c|c|}
\hline & T1 (control) & T2 (urea) & T3 (UMMB) \\
\hline DM intake $(g / d)$ & $6432^{a}$ & $6209^{a}$ & $5571^{b}$ \\
\hline DM digestibility (\%) & 61.6 & 59.0 & 59.6 \\
\hline CP digestibility (\%) & 70.4 & 67.9 & 64.8 \\
\hline CF digestibility (\%) & 49.2 & 48.3 & 49.1 \\
\hline$N$-intake $(g / d)$ & $133^{a}$ & $127^{a}$ & $114 b$ \\
\hline$N$-retained $(g / d)$ & $51^{a}$ & $43^{a b}$ & 310 \\
\hline Initial Body weight (kg) & 258 & 260 & 262 \\
\hline Daily gain $(\mathrm{g} / \mathrm{d})$ & $565^{a}$ & $512^{\mathrm{b}}$ & $550^{a}$ \\
\hline
\end{tabular}

Mean values with different superscripts (a, b) within the same row differ significantly $(P<0.05)$. 